\title{
The Associations of Common Genetic Susceptibility Variants with Breast Cancer in Jordanian Arabs: A Case-Control Study
}

\author{
Laith N AL-Eitan'*, Doaa M Rababa'h², Hatem A Aman ${ }^{2}$
}

\begin{abstract}
Objective: In Jordan, breast cancer (BC) affects a substantial proportion of Jordanian women, highlighting the need for studies to be carried out regarding the genetic component of the disease. The aim of the present study was to investigate the interaction between BC risk and prognosis and polymorphisms in genes (ATM, CASP8, FGFR2, FN1, $I G F 1, L S P 1, M A P 3 K, M M P 7$, and $R H O C$ ) that were chosen for this study previously reported as having a role in the disease. Materials and Methods: Blood samples were collected from 242 BC patients and 231 disease-free volunteers recruited from the Jordanian population. DNA was extracted from blood and each sample was sent to the Australian Genome Research Facility for genotyping. Results: The rs 1219648 SNP of the FGFR2 gene was the only investigated variant to show any direct association with $\mathrm{BC}$ in Jordanian women (p-value $=0.04)$. However, the CASP8rs6760993 SNP was found to be significantly associated with BC ( $\mathrm{p}$-value $=0.04$ ) when using the dominant model. Other gene polymorphisms showed varying levels of association between some investigated SNPs and different BC risk and prognostic factors. Conclusion: Despite reports to the contrary in other populations, most of the investigated genes and their respective SNPs did not show any significant association with BC in Jordanian women. Our results underline the need for independent $\mathrm{BC}$ research to be carried out in the Jordanian population to decipher the genetic basis of the disease.
\end{abstract}

Keywords: Breast cancer - CASP8 - FGFR2 - IGF1 - LSP1 - MAP3K1- Jordanian

Asian Pac J Cancer Prev, 21 (10), 3045-3054

\section{Introduction}

Breast cancer (BC) is the most common malignancy in Jordanian women, accounting for $37.3 \%$ of female cancers reported in that country (Abdel-Razeq et al., 2015; AL-Eitan et al., 2017; AL-Eitan et al., 2019). Although its etiology is still not clearly understood, BC risk and development is known to be influenced by a combination of endogenous hormone levels, lifestyle factors, and individual genetic susceptibility (Hankinson et al., 2004; AL-Eitan et al., 2019; AL-Eitan et al., 2020). Around $5-10 \%$ of BC cases are caused primarily by genetic mutations (AL-Eitan and Rababa'h, 2019), and of those, the vast majority of genetic influence lies with the BRCA1 and BRCA2 mutations (Gage et al., 2012; AL-Eitan et al., 2017). The remainder of genetic susceptibility to BC can be attributed to mutations that lead to the activation and disruption of proto-oncogenes and tumor suppressor genes, respectively (Lee and Muller, 2010; AL-Eitan et al., 2017; AL-Eitan et al., 2019). Proto-oncogenes are those genes that are involved in cell growth and proliferation, with potential examples including the $A T M, F G F R 2$, FN1, IGF1, MAP $3 K, M M P 7$, and RHOC genes, while the CASP 8 and LSP1 genes have been reported to possess tumor-suppressive properties in certain types of cancer.

Serine/threonine kinase expression has been found to be frequently modulated in human cancers (Capra et al., 2006). The ATM serine/threonine kinase (ATM) gene is involved in the activation of the DNA damage checkpoint, and mutations in this gene are responsible for the autosomal recessive syndrome ataxia-telangiectasia (Lavin et al., 2006). In addition, studies have shown that unaffected carriers of ATM mutations are more susceptible to $\mathrm{BC}$ compared to controls and have a lifetime $\mathrm{BC}$ risk of more than 25\% (Renwick et al., 2006; Ahmed and Rahman, 2006). Similarly, the mitogen-activated protein kinase 1 (MAP3K1) gene is a serine/threonine kinase that activates mutagenic downstream signaling pathways, and its mutations have been significantly associated with luminal BC (Jerzak et al., 2018). In fact, MAP3K1 mutations resulted in increased susceptibility to $\mathrm{BC}$ and were especially associated with estrogen- and progesterone-receptor positive BC tumors (Pham et al., 2013).

Growth factors and their receptors have also been implicated in cancer development, particularly in tumor

${ }^{1}$ Department of Applied Biological Sciences, Jordan University of Science and Technology, Irbid 22110, Jordan. ${ }^{2}$ Department of Biotechnology and Genetic Engineering, Jordan University of Science and Technology, Irbid 22110, Jordan. *For Correspondence: Ineitan@just.edu.jo 
metastasis (Rebbeck et al., 2008). The fibroblast growth factor receptor 2 (FGFR2) genes are involved in tissue repair, and its mutated forms are associated with autosomal dominant skeletal and cranial disorders (Yang et al., 2011). Moreover, FGFR2 mutations have been reported in a diverse range of cancer types including $\mathrm{BC}$, and FGFR inhibitors reported to have a direct anti-tumor effect on cancer cells (Jang et al., 2000; Helsten et al., 2016). In a similar fashion, the insulin-like growth factor 1 (IGF1) gene exerts anabolic effects via suppression of apoptosis, and high expression levels of this gene play an important role in cancer (Katoh, 2016). Furthermore, a large number of studies point towards the role of the IGF1 system in $\mathrm{BC}$ initiation and development (Brahmkhatri et al., 2015).

Aberrant expressions of various membrane-associated G-proteins, matrix metalloproteinase, and glycoproteins have been extensively recorded in tumors (Christopoulos et al., 2015; Bar-Shavit et al., 2016). The RHOC gene encodes for the RhoC signaling $G$ protein that, when overexpressed, is involved in cell proliferation and tumor malignancy (Gialeli et al., 2011). In the context of BC, RhoC overexpression is associated with a worse prognosis and is needed for tissue invasion to occur (Horiuchi et al., 2003).

Likewise, the matrix metalloproteinase-7 (MMP7) gene, which is normally responsible for tissue remodeling, is overexpressed in cases of tissue invasion as well as tumor formation (Lang et al., 2017). Different polymorphisms in the MMP7 gene have been associated with both improved and worsened $\mathrm{BC}$ prognosis in Chinese patients (Basu et al., 2015). Finally, the fibronectin 1 (FN1) gene is an extracellular matrix glycoprotein that is involved in cell proliferation under homeostatic conditions but promotes metastasis of tumor cells when its expression is modulated (Beeghly-Fadiel et al., 2009). Moreover, it has been reported that FN1 expression levels are associated with $\mathrm{BC}$ prognosis and invasion (Wang and Hielscher, 2017; Wang et al., 2018). On the other hand, high expression of the caspase 8 (CASP8) and lymphocyte-specific protein 1 (LSP1) genes are associated with tumor inhibition in most cases (Helleman et al., 2008; Zhang et al., 2016). CASP8 normally functions as a part of cell apoptosis, and $C A S P 8$ mutations have been associated with resistance to apoptosis as well as malignant transformation in head and neck cancer (Graf et al., 2014; Li et al., 2014).

Furthermore, CASP8 mutations exacerbate the risk of certain BC subtypes, but they are not associated with adverse BC survival rates (Ando et al., 2013; Park et al., 2016). Similarly, the $L S P 1$ gene has been reported to inhibit hepatocellular carcinoma growth as a part of its normal function, while LSP1 mutations have been found to increase BC susceptibility in both Caucasian and Han Chinese women (Zhang et al., 2016; Pu et al., 2017; Vachon et al., 2012). Since lifestyle factors and endogenous hormone levels also influence $\mathrm{BC}$ risk and development, the main aim of this study is to ascertain whether there is an association between $\mathrm{BC}$ risk and prognosis and single nucleotide polymorphisms (SNPs) in certain genes in the Jordanian population. The ATM, CASP8, FGFR2, FN1, IGF1, LSP1, MAP3K, MMP7, and $R H O C$ genes were chosen for this study because of their reported roles in $\mathrm{BC}$ in populations other than Jordanians such as Caucasian (Chen et al., 2015; Easton et al., 2007; Zhang et al., 2011; Sadek et al., 2017).

\section{Materials and Methods}

\section{Subjects}

This study conducted on $221 \mathrm{BC}$ female patients and 218 healthy individuals recruited from the Jordanian Arab population as shown in Figure 1. The data used was obtained from a previous case-control study (AL-Eitan et al., 2017). Collected data encompassed factors associated with $\mathrm{BC}$ risk (ages at $\mathrm{BC}$ diagnosis, first pregnancy, menarche, and menopause, allergy, body mass index, breastfeeding status, co-morbidity, family history, and smoking) and prognosis (axillary lymph node status, estrogen, progesterone, and HER2 receptor status, histological classification, molecular subtypes and tumor differentiation, size and stage). In addition, blood samples were withdrawn from the cases and controls for subsequent DNA extraction.

\section{DNA extraction and Genotyping}

DNA was extracted from the blood samples using the Wizard $^{\circledR}$ Genomic DNA Purification Kit (Promega Corp., USA) for subsequent quantification and qualification on the Nano-Drop ND-1000 UV-Vis Spectrophotometer (BioDrop, UK). Diluted samples with final concentrations of $20 \mathrm{ng} / \mu \mathrm{l}$ were then shipped on wet ice to the Australian Genome Research Facility (AGRF) in Melbourne for genotyping on the SequenomMassARRAY ${ }^{\circledR}$ system (iPLEX GOLD) (Sequenom, USA).

\section{Statistical analysis}

All investigated SNPs in the cases and controls were tested to fulfill the Hardy-Weinberg equilibrium (Rodriguez et al., 2009). Variations between cases and controls were calculated by employing Pearson's chi-squared using the Statistical Package for the Social Sciences (SPSS), version 25.0 (SPSS, Inc., Chicago, IL). SNPStats software was utilized for the haplotypic analysis in addition to different genetic model analysis (Sole et al., 2006). The odds ratio (OR) was also calculated using binary logistic regression with $95 \%$ confidence intervals (CI). A p-value of 0.05 or lower is considered statistically significant.

\section{Correction for Multiple Testing}

However, when multiple comparison tests apply according to the method published by (Li and Ji, 2005) to estimate the effective number of SNPs (Nem) that employs a modification of an earlier approach by Nyholt (2004) . Modified Bonferroni procedure was applied to determine a target alpha level $(0.05 / \mathrm{Nem})$ that would maintain an overall significance level of 0.05 or less.

\section{Results}

Samples characteristics

In this study, the general characteristics for controls were summarized and categorized in previously published 
The Associations of Common Genetic Susceptibility Variants with Breast Cancer in Jordanian Arabs: A Case-Control Study

study by (AL-Eitan et al., 2017). Unrelated healthy females were randomly selected from the Jordanian population with an average age of $50.8 \pm 12.6$ years.Data obtained for this study were available for 219 female patients who were diagnosed with $\mathrm{BC}$. The averages ages of participantsat $\mathrm{BC}$ diagnosis $(51.1 \pm 16.5)$, at pregnancy $(22.6 \pm 2)$, age at menarche $(13.8 \pm 0)$ and age at menu pause $(48.31 \pm 4.5)$. The average body mass index (BMI) was $31.28 \pm 3.48$ for the patient group. Besides, Table 1 describes the clinical and pathological features of $\mathrm{BC}$ patients in this study. Three Molecular subtypes of BC depending on estrogen, progesterone, and HER2 status were investigated in this study: luminal A (L. A): ER(+) and /or PR(+) Her2 (-), luminal B (L.B): ER(+) and / or PR(+) Her2 (+), triple-negative (T.N): ER(-) and /or PR(- ) Her2 (-) (Sadek et al., 2017). We found that $47 \%$ of patients were L.A, $41 \%$ were L.B while $12 \%$ were T.N.

\section{Genes and their minor allelic frequencies}

Table 2 depicts the candidate genes and their associated polymorphisms. It also illustrates the distribution of the minor allele of each SNP in the cases and controls along with the Hardy-Weinberg equilibrium p-values. All the investigated SNPs were in accordance with HWEexcept for $r s 599774$ of the LSP1 gene, which was excluded.

Association of investigated SNPs with breast cancer (BC)

In this study, the correlation between $\mathrm{BC}$ and the candidate polymorphisms were investigated. The FGFR2 rs1219648 SNP was associated with BC $(p$-value $=0.041)$, but no such association was found for the other studied SNPs, nor were there any significant differences in the allelic and genotypic frequencies between the cases and controls as shown in Table 3 . Different genetic models were then incorporated into the analysis to further ascertain the extent of association, and only the CASP8 rs6760993 SNP was found to be significantly associated with $\mathrm{BC}(\mathrm{p}$-value $=0.04)$ upon employing the dominant model are shown in Table 4.

Association of investigated SNPS with breast cancer (BC) risk and prognosis

In addition to direct association with the disease, the SNPs included in this study were tested for association with the factors involved in BC risk and prognosis (Tables 5 and 6). The CASP8 rs6760993 SNP was significantly

Table 1. Clinical and Pathological Features of BC Patients

\begin{tabular}{|c|c|c|c|c|}
\hline \multirow{2}{*}{$\begin{array}{l}\text { Clinical Characteristics } \\
\text { BMI }\end{array}$} & \multirow[t]{2}{*}{ Frequency $(n=219)$} & \multicolumn{2}{|c|}{ Pathological Characteristics } & \multirow{2}{*}{$\begin{array}{l}\text { Frequency } \\
(n=219)\end{array}$} \\
\hline & & & & \\
\hline$<=25$ & $24.00 \%$ & Progesterone Receptor Status & Positive & $44 \%$ \\
\hline$>25$ & $76.00 \%$ & & Negative & $55 \%$ \\
\hline \multicolumn{5}{|l|}{ First Pregnancy (Age) } \\
\hline$<20$ & $19.00 \%$ & Estrogen Receptor & Positive & $74.00 \%$ \\
\hline$>=20$ & $81.00 \%$ & & Negative & $26.00 \%$ \\
\hline \multicolumn{5}{|c|}{ Age at Breast Cancer Diagnosis } \\
\hline$<45$ & $34.00 \%$ & Tumor Differentiation & Low Differentiation & $38.00 \%$ \\
\hline$>=45$ & $66.00 \%$ & & Mid \& High. Differentiation & $62.00 \%$ \\
\hline \multicolumn{5}{|l|}{ Age at First Menstruation } \\
\hline$<13$ & $30.00 \%$ & Axillary Lymph Nodes & Free of tumor & $49.00 \%$ \\
\hline$>=13$ & $70.00 \%$ & & Show Metastatic Carcinoma & $51.00 \%$ \\
\hline \multicolumn{5}{|l|}{ Breastfeeding Status } \\
\hline Yes & $66.30 \%$ & Tumor Stage & PT1-PT2 & $90.00 \%$ \\
\hline No & $33.70 \%$ & & PT3-PT4 & $10.00 \%$ \\
\hline \multicolumn{5}{|l|}{ Age at Menopause } \\
\hline$<50$ & $46.70 \%$ & Histology Classification & In Situ Carcinoma & $20.00 \%$ \\
\hline$>=50$ & $53.30 \%$ & & Invasive Carcinoma & $80.00 \%$ \\
\hline \multicolumn{5}{|l|}{ Family History } \\
\hline Yes & $32.00 \%$ & Tumor Size (CM3) & $<=2$ & $20.00 \%$ \\
\hline No & $68.00 \%$ & & $x>2$ & $80.00 \%$ \\
\hline \multicolumn{5}{|l|}{ Allergy } \\
\hline Yes & $27.00 \%$ & Lymph Node Involvement & Yes & $82.00 \%$ \\
\hline No & $73.00 \%$ & & No & $18.00 \%$ \\
\hline \multicolumn{5}{|l|}{ Smoking } \\
\hline Yes & $30.00 \%$ & Human Epidermal Growth Factor & Positive & $30.00 \%$ \\
\hline No & $70.00 \%$ & Receptor 2 (Her2) Marker & & \\
\hline \multicolumn{5}{|l|}{ Co-morbidity } \\
\hline Yes & $46.00 \%$ & & & \\
\hline No & $54.00 \%$ & & Negative & $60.00 \%$ \\
\hline
\end{tabular}


Table 2. Minor Allele Frequencies and Hardy-Weinberg $P$-values of Candidate Gene SNPs

\begin{tabular}{|c|c|c|c|c|c|c|c|}
\hline \multirow[t]{2}{*}{ Gene } & \multirow[t]{2}{*}{ SNP ID } & \multicolumn{3}{|c|}{ Cases $(n=221)$} & \multicolumn{3}{|c|}{ Controls $(\mathrm{n}=218)$} \\
\hline & & $\mathrm{MA}^{\mathrm{a}}$ & $\mathrm{MAF}^{\mathrm{b}}$ & $\mathrm{HWE}^{\mathrm{c}} P$-Value & $\mathrm{MA}^{\mathrm{a}}$ & $\mathrm{MAF}^{\mathrm{b}}$ & $\mathrm{HWE}^{\mathrm{c}} P$-Value \\
\hline \multirow[t]{2}{*}{$A T M$} & rs1800889 & $\mathrm{T}$ & N/A & NA & $\mathrm{T}$ & 0.01 & NA \\
\hline & rs1801516 & A & 0.08 & 0.18 & A & 0.08 & NA \\
\hline CASP8 & rs6760993 & A & 0.39 & 0.2 & A & 0.35 & 0.17 \\
\hline \multirow[t]{2}{*}{ FGFR2 } & rs1219648 & G & 0.49 & NA & G & 0.42 & 0.58 \\
\hline & rs2981582 & A & 0.43 & 0.49 & A & 0.5 & 0.79 \\
\hline FN1 & rs 10207245 & $\mathrm{~A}$ & 0.32 & 0.12 & A & 0.32 & 0.88 \\
\hline$I G F 1$ & rs 2373721 & G & 0.29 & 0.41 & G & 0.31 & 0.15 \\
\hline \multirow[t]{2}{*}{$L S P 1$} & rs599774 & $\mathrm{G}$ & 0.37 & 0.01 & G & 0.33 & 0.02 \\
\hline & rs661348 & $\mathrm{C}$ & 0.34 & 0.37 & $\mathrm{C}$ & 0.32 & 0.76 \\
\hline$M A P 3 K 1$ & rs889312 & $\mathrm{C}$ & 0.37 & 0.08 & $\mathrm{C}$ & 0.55 & 0.34 \\
\hline$M M P 7$ & rs1943779 & $\mathrm{C}$ & 0.37 & 0.77 & $\mathrm{C}$ & 0.34 & 0.88 \\
\hline RHOC & rs2999156 & $\mathrm{G}$ & 0.40 & 0.89 & $\mathrm{G}$ & 0.44 & 0.22 \\
\hline
\end{tabular}

${ }^{a}$ MA, Minor Allele; ${ }^{b}$ MAF, Minor Allele Frequency; ${ }^{\mathrm{c} H W E}$, Hardy-Weinberg Equilibrium; NA, Not Applicable.

associated with age at menarche ( $\mathrm{p}$-value $=0.001)$. Smoking was significantly associated with the FGFR2 SNP rs1219648 (p-value $=0.01)$ and the FN1 SNP rs10207245 (p-value $=0.01$ ), and age at menopause was linked to the FGFR2 SNP rs1219648 (p-value = 0.02). Also, the IGF1 SNP rs 2373721 was associated with family history of $\mathrm{BC}(\mathrm{p}$-value $=0.01)$. With regard to the prognostic factors, the FGFR2 SNP rs1219648 was associated with tumor differentiation ( $p$-value $=$ 0.018), the MAP3K1 SNP rs889312 was linked to the HER2 marker ( $\mathrm{p}$-value $=0.04)$, and the IGF1 SNP rs2373721 was correlated with progesterone receptor status ( $\mathrm{p}$-value $=0.04$ ).

Additionally, estrogen receptor status was significantly associated with both the LSP1 SNP rs661348 (p-value = 0.02) and the MMP7 SNP rs1943779 (p-value =0.01).

\section{Haplotype analysis}

Haplotypes involving two FGFR2 loci are summarized in Table 7. A significant difference in the frequency of the FGFR2 GA haplotype was found between cases and controls $(p$-value $=0.04)$, suggesting a reduction in $\mathrm{BC}$ risk.

\section{Discussion}

Despite affecting one in five Jordanian women, breast cancer $(\mathrm{BC})$ has been the subject of a relatively limited number of studies in Jordan (AL-Eitan et al., 2019; AL-Eitan et al., 2019; AL-Eitan et al., 2019; ALEitan et al., 2019; AL-Eitan et al., 2019; AL-Eitan et al., 2019, AL-Eitan et al., 2019). Protective factors against $\mathrm{BC}$ among Jordanian women involved physical activity as well as frequent fruit and vegetable intake, while calcium intake of more than three times a week and postmenopausal obesity were associated with increased $\mathrm{BC}$ risk (Al Qadire et al., 2018; Atoum and Al-Hourani, 2004). In terms of genetic association studies, BC risk

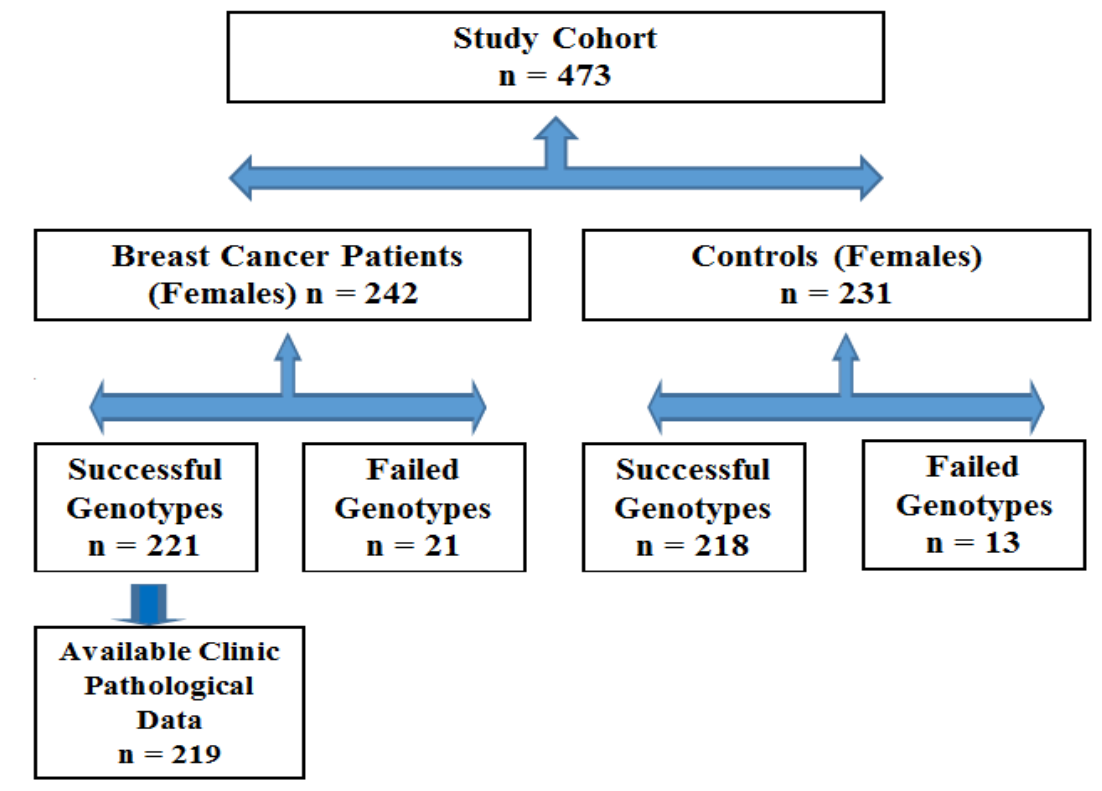

Figure 1. A Consort Diagram Of BC Patients and Controls Detailing Inclusion and Exclusion Criteria 
The Associations of Common Genetic Susceptibility Variants with Breast Cancer in Jordanian Arabs: A Case-Control Study Table 3. Association of the Candidate Gene SNPs with Breast Cancer (BC)

\begin{tabular}{|c|c|c|c|c|c|c|}
\hline \multirow[t]{2}{*}{ Gene } & \multirow[t]{2}{*}{ SNP ID } & \multicolumn{5}{|c|}{ Allelic and Genotypic Frequencies in Cases and Controls } \\
\hline & & Allele/Genotype & Cases $(n=221)$ & Controls $(\mathrm{n}=218)$ & P-value & Chi-square \\
\hline \multirow[t]{9}{*}{$A T M$} & rs 1800889 & $\mathrm{C}$ & $442(100)$ & 433(99) & 0.09 & 2.91 \\
\hline & & $\mathrm{T}$ & $0(-)$ & $3(01)$ & & \\
\hline & & $\mathrm{CC}$ & $221(100)$ & $215(99)$ & 0.08 & 3.06 \\
\hline & & $\mathrm{CT}$ & $0(-)$ & $3(0.01)$ & & \\
\hline & rs 1801516 & $\mathrm{G}$ & $405(92)$ & $402(92)$ & 0.755 & 0.09 \\
\hline & & A & $37(08)$ & $34(08)$ & & \\
\hline & & $\mathrm{G} / \mathrm{G}$ & $187(84.6)$ & $185(84.9)$ & 0.60 & 1.01 \\
\hline & & $\mathrm{A} / \mathrm{G}$ & $31(14)$ & $32(14.7)$ & & \\
\hline & & $\mathrm{A} / \mathrm{A}$ & $3(1.4)$ & $1(0.5)$ & & \\
\hline \multirow[t]{5}{*}{ CASP8 } & rs6760993 & $\mathrm{G}$ & $268(61)$ & 277 (65) & 0.20 & 1.59 \\
\hline & & $\mathrm{A}$ & 170 (39) & $147(35)$ & & \\
\hline & & $\mathrm{G} / \mathrm{G}$ & $77(35.2)$ & 95 (44.8) & 0.06 & 5.46 \\
\hline & & $\mathrm{A} / \mathrm{G}$ & $114(52)$ & $87(41)$ & & \\
\hline & & $\mathrm{A} / \mathrm{A}$ & $28(12.8)$ & $30(14.2)$ & & \\
\hline \multirow[t]{10}{*}{ FGFR2 } & rs1219648 & $\mathrm{A}$ & $223(0.51)$ & $252(0.58)$ & 0.04 & 4.17 \\
\hline & & $\mathrm{G}$ & $215(0.49)$ & $184(0.42)$ & & \\
\hline & & $\mathrm{A} / \mathrm{A}$ & $57(26)$ & $75(34.4)$ & 0.12 & 4.21 \\
\hline & & $\mathrm{A} / \mathrm{G}$ & $109(49.8)$ & $102(46.8)$ & & \\
\hline & & $\mathrm{G} / \mathrm{G}$ & $53(24.2)$ & $41(18.8)$ & & \\
\hline & rs2981582 & $\mathrm{G}$ & $219(50)$ & $248(57)$ & 0.06 & 3.60 \\
\hline & & A & $215(50)$ & $188(43)$ & & \\
\hline & & $\mathrm{G} / \mathrm{G}$ & $54(24.9)$ & $73(33.5)$ & 0.13 & 4.07 \\
\hline & & $\mathrm{G} / \mathrm{A}$ & $111(51.1)$ & $102(46.8)$ & & \\
\hline & & $\mathrm{A} / \mathrm{A}$ & $52(24)$ & 43 (19.7) & & \\
\hline \multirow[t]{5}{*}{ FN1 } & rs 10207245 & $\mathrm{~T}$ & $296(68)$ & $293(68)$ & 0.86 & 0.03 \\
\hline & & A & $142(32)$ & $137(32)$ & & \\
\hline & & $\mathrm{T} / \mathrm{T}$ & $105(48)$ & $99(46)$ & 0.45 & 1.58 \\
\hline & & $\mathrm{T} / \mathrm{A}$ & $86(39.3)$ & 95 (44.2) & & \\
\hline & & $\mathrm{A} / \mathrm{A}$ & $28(12.8)$ & $21(9.8)$ & & \\
\hline \multirow[t]{5}{*}{$I G F 1$} & rs 2373721 & $\mathrm{C}$ & $313(0.71)$ & $303(0.69)$ & 0.59 & 0.28 \\
\hline & & $\mathrm{G}$ & $127(0.29)$ & $133(0.31)$ & & \\
\hline & & $\mathrm{C} / \mathrm{C}$ & $114(51.8)$ & $110(50.5)$ & 0.80 & 0.43 \\
\hline & & $\mathrm{G} / \mathrm{C}$ & 85 (38.6) & $83(38.1)$ & & \\
\hline & & $\mathrm{G} / \mathrm{G}$ & $21(9.6)$ & $25(11.5)$ & & \\
\hline \multirow[t]{5}{*}{$L S P 1$} & rs661348 & $\mathrm{T}$ & $293(66)$ & 297 (68) & 0.56 & 0.33 \\
\hline & & $\mathrm{C}$ & $149(34)$ & $139(32)$ & & \\
\hline & & $\mathrm{T} / \mathrm{T}$ & $100(45.2)$ & $102(46.8)$ & 0.78 & 0.49 \\
\hline & & $\mathrm{C} / \mathrm{T}$ & $93(42.1)$ & 93 (42.7) & & \\
\hline & & $\mathrm{C} / \mathrm{C}$ & $28(12.7)$ & $23(10.6)$ & & \\
\hline
\end{tabular}

$P$-Value $<0.05$ was considered as significant.

in Jordanians was linked to mutations in the BRCA1, DAPK1, MMP9, MTHFR, TP53, and TOX3 genes (Atoum and Al-Kayed, 2004; Awwad et al., 2015). The aim of the present study was to determine the extent of the relationship between SNPs in the ATM, CASP8, FGFR2, IGF1, LSP1, MAP3K, MMP7, and RHOC genes and BC risk and prognosis. To the best of the authors' knowledge, no other study has attempted to understand such interplay between genetic and environmental factors in $\mathrm{BC}$ in the
Jordanian population. The findings of the present study indicate that the $r s 1219648$ SNP of the FGFR2 gene is significantly but slightly associated with $\mathrm{BC}$ in Jordanian women $(p$-value $=0.04)$. Hormones related risk factors such as age at first menstruation, age at menopause and age at first pregnancy may influence the development of breast cancer disease among females, because of the exposure time to endogenous estrogen. In addition, these factors may increase the risk among patients with mutant 
Table 4. Incorporating Different Genetic Models to Carry out Genetic Association Analysis between Candidate Gene SNPs and Breast Cancer (BC)

\begin{tabular}{|c|c|c|c|c|c|c|c|}
\hline Gene & SNP ID & Model & Genotype & Cases $(\%)$ & Controls (\%) & $\begin{array}{c}\text { OR } \\
(95 \% \mathrm{CI})\end{array}$ & P-Value \\
\hline \multirow[t]{4}{*}{ ATM } & rs1801516 & Dominant & $\mathrm{G} / \mathrm{G}$ & $187(84.6 \%)$ & $185(84.9 \%)$ & 1 & 0.94 \\
\hline & & & $\mathrm{A} / \mathrm{G}-\mathrm{A} / \mathrm{A}$ & $34(15.4 \%)$ & $33(15.1 \%)$ & $1.02(0.61-1.71)$ & \\
\hline & & Recessive & G/G-A/G & $218(98.6 \%)$ & $217(99.5 \%)$ & 1 & 0.31 \\
\hline & & & $\mathrm{A} / \mathrm{A}$ & $3(1.4 \%)$ & $1(0.5 \%)$ & $2.99(0.31-28.93)$ & \\
\hline \multirow[t]{4}{*}{ CASP8 } & rs6760993 & Dominant & $\mathrm{G} / \mathrm{G}$ & $77(35.2 \%)$ & $95(44.8 \%)$ & 1 & 0.04 \\
\hline & & & $\mathrm{A} / \mathrm{G}-\mathrm{A} / \mathrm{A}$ & $142(64.8 \%)$ & $117(55.2 \%)$ & $1.50(1.02-2.21)$ & \\
\hline & & Recessive & G/G-A/G & $191(87.2 \%)$ & $182(85.8 \%)$ & 1 & 0.68 \\
\hline & & & $\mathrm{A} / \mathrm{A}$ & $28(12.8 \%)$ & $30(14.2 \%)$ & $0.89(0.51-1.55)$ & \\
\hline \multirow[t]{8}{*}{ FGFR2 } & rs 1219648 & Dominant & $\mathrm{A} / \mathrm{A}$ & $57(26 \%)$ & $75(34.4 \%)$ & 1 & 0.05 \\
\hline & & & A/G-G/G & $162(74 \%)$ & $143(65.6 \%)$ & $1.49(0.99-2.25$ & \\
\hline & & Recessive & $\mathrm{A} / \mathrm{A}-\mathrm{A} / \mathrm{G}$ & $166(75.8 \%)$ & $177(81.2 \%)$ & 1 & 0.17 \\
\hline & & & $\mathrm{G} / \mathrm{G}$ & $53(24.2 \%)$ & $41(18.8 \%)$ & $1.38(0.87-2.18)$ & \\
\hline & rs2981582 & Dominant & $\mathrm{G} / \mathrm{G}$ & $54(24.9 \%)$ & $73(33.5 \%)$ & 1 & 0.05 \\
\hline & & & $\mathrm{G} / \mathrm{A}-\mathrm{A} / \mathrm{A}$ & $163(75.1 \%)$ & $145(66.5 \%)$ & $1.52(1.00-2.31)$ & \\
\hline & & Recessive & G/G-G/A & $165(76 \%)$ & $175(80.3 \%)$ & 1 & 0.28 \\
\hline & & & $\mathrm{A} / \mathrm{A}$ & $52(24 \%)$ & $43(19.7 \%)$ & $1.28(0.81-2.02)$ & \\
\hline \multirow[t]{4}{*}{ FN1 } & rs 10207245 & Dominant & $\mathrm{T} / \mathrm{T}$ & $105(48 \%)$ & $99(46 \%)$ & 1 & 0.69 \\
\hline & & & $\mathrm{T} / \mathrm{A}-\mathrm{A} / \mathrm{A}$ & $114(52 \%)$ & $116(54 \%)$ & $0.93(0.64-1.35)$ & \\
\hline & & Recessive & $\mathrm{T} / \mathrm{T}-\mathrm{T} / \mathrm{A}$ & $191(87.2 \%)$ & $194(90.2 \%)$ & 1 & 0.32 \\
\hline & & & $\mathrm{A} / \mathrm{A}$ & $28(12.8 \%)$ & $21(9.8 \%)$ & $1.35(0.74-2.47)$ & \\
\hline \multirow[t]{4}{*}{$I G F 1$} & rs2373721 & Dominant & $\mathrm{C} / \mathrm{C}$ & $114(51.8 \%)$ & $110(50.5 \%)$ & 1 & 0.78 \\
\hline & & & $\mathrm{G} / \mathrm{C}-\mathrm{G} / \mathrm{G}$ & $106(48.2 \%)$ & $108(49.5 \%)$ & $0.95(0.65-1.38)$ & \\
\hline & & Recessive & $\mathrm{C} / \mathrm{C}-\mathrm{G} / \mathrm{C}$ & $199(90.5 \%)$ & $193(88.5 \%)$ & 1 & 0.51 \\
\hline & & & $\mathrm{G} / \mathrm{G}$ & $21(9.6 \%)$ & $25(11.5 \%)$ & $0.81(0.44-1.50)$ & \\
\hline \multirow[t]{4}{*}{$L S P 1$} & rs661348 & Dominant & $\mathrm{T} / \mathrm{T}$ & $100(45.2 \%)$ & $102(46.8 \%)$ & 1 & 0.75 \\
\hline & & & $\mathrm{C} / \mathrm{T}-\mathrm{C} / \mathrm{C}$ & $121(54.8 \%)$ & $116(53.2 \%)$ & $1.06(0.73-1.55)$ & \\
\hline & & Recessive & $\mathrm{T} / \mathrm{T}-\mathrm{C} / \mathrm{T}$ & $193(87.3 \%)$ & $195(89.5 \%)$ & 1 & 0.49 \\
\hline & & & $\mathrm{C} / \mathrm{C}$ & $28(12.7 \%)$ & $23(10.6 \%)$ & $1.23(0.68-2.21)$ & \\
\hline \multirow[t]{4}{*}{$M M P 7$} & rs1943779 & Dominant & $\mathrm{T} / \mathrm{T}$ & $88(39.8 \%)$ & $94(43.3 \%)$ & 1 & 0.46 \\
\hline & & & $\mathrm{T} / \mathrm{C}-\mathrm{C} / \mathrm{C}$ & $133(60.2 \%)$ & $123(56.7 \%)$ & $1.16(0.79-1.69)$ & \\
\hline & & Recessive & $\mathrm{T} / \mathrm{T}-\mathrm{T} / \mathrm{C}$ & $189(85.5 \%)$ & $191(88 \%)$ & 1 & 0.44 \\
\hline & & & $\mathrm{C} / \mathrm{C}$ & $32(14.5 \%)$ & $26(12 \%)$ & $1.24(0.71-2.17$ & \\
\hline \multirow[t]{4}{*}{$M A P 3 K 1$} & rs889312 & Dominant & $\mathrm{A} / \mathrm{A}$ & $94(42.5 \%)$ & $97(44.5 \%)$ & 1 & 0.68 \\
\hline & & & $\mathrm{C} / \mathrm{A}-\mathrm{C} / \mathrm{C}$ & $127(57.5 \%)$ & $121(55.5 \%)$ & $1.08(0.74-1.58)$ & \\
\hline & & Recessive & $\mathrm{A} / \mathrm{A}-\mathrm{C} / \mathrm{A}$ & $185(83.7 \%)$ & $191(87.6 \%)$ & 1 & 0.24 \\
\hline & & & $\mathrm{C} / \mathrm{C}$ & $36(16.3 \%)$ & $27(12.4 \%)$ & $1.38(0.80-2.36)$ & \\
\hline \multirow[t]{4}{*}{ RHOC } & rs2999156 & Dominant & $\mathrm{C} / \mathrm{C}$ & $79(35.9 \%)$ & $64(29.4 \%)$ & 1 & 0.14 \\
\hline & & & $\mathrm{C} / \mathrm{G}-\mathrm{G} / \mathrm{G}$ & $141(64.1 \%)$ & $154(70.6 \%)$ & $0.74(0.50-1.11)$ & \\
\hline & & Recessive & $\mathrm{C} / \mathrm{C}-\mathrm{C} / \mathrm{G}$ & $184(83.6 \%)$ & $181(83 \%)$ & 1 & 0.86 \\
\hline & & & $\mathrm{G} / \mathrm{G}$ & $36(16.4 \%)$ & $37(17 \%)$ & $0.96(0.58-1.58)$ & \\
\hline
\end{tabular}

P- Value $<0.05$ was considered as significant; OR, Odd Ratio; CI, Confidence Interval.

allele/ genotype.

rs 1219648 was found to be significantly associated with age at menopause $(\mathrm{p}$-value $=0.02)$, smoking $(\mathrm{p}$-value $=$ 0.01 ), and tumor differentiation ( $\mathrm{p}$-value $=0.02$ ). Lifestyle habit such as smoking is considered as a cancer risk factor, we hypothesized that smoker patients with $\mathrm{BC}$ may be at increased risk when carrying mutant alleles. rs 1219648 of FGFR2 was significantly associated with smoking status; we found that $39 \%$ of smoking cases were carrying AA genotype, while $19 \%$ of the nonsmoking cohorts were with the same genotype. Furthermore, $13 \%$ of smoking cases were carrying the GG genotype compared to $29 \%$ of 
DOI:10.31557/APJCP.2020.21.10.3045

The Associations of Common Genetic Susceptibility Variants with Breast Cancer in Jordanian Arabs: A Case-Control Study
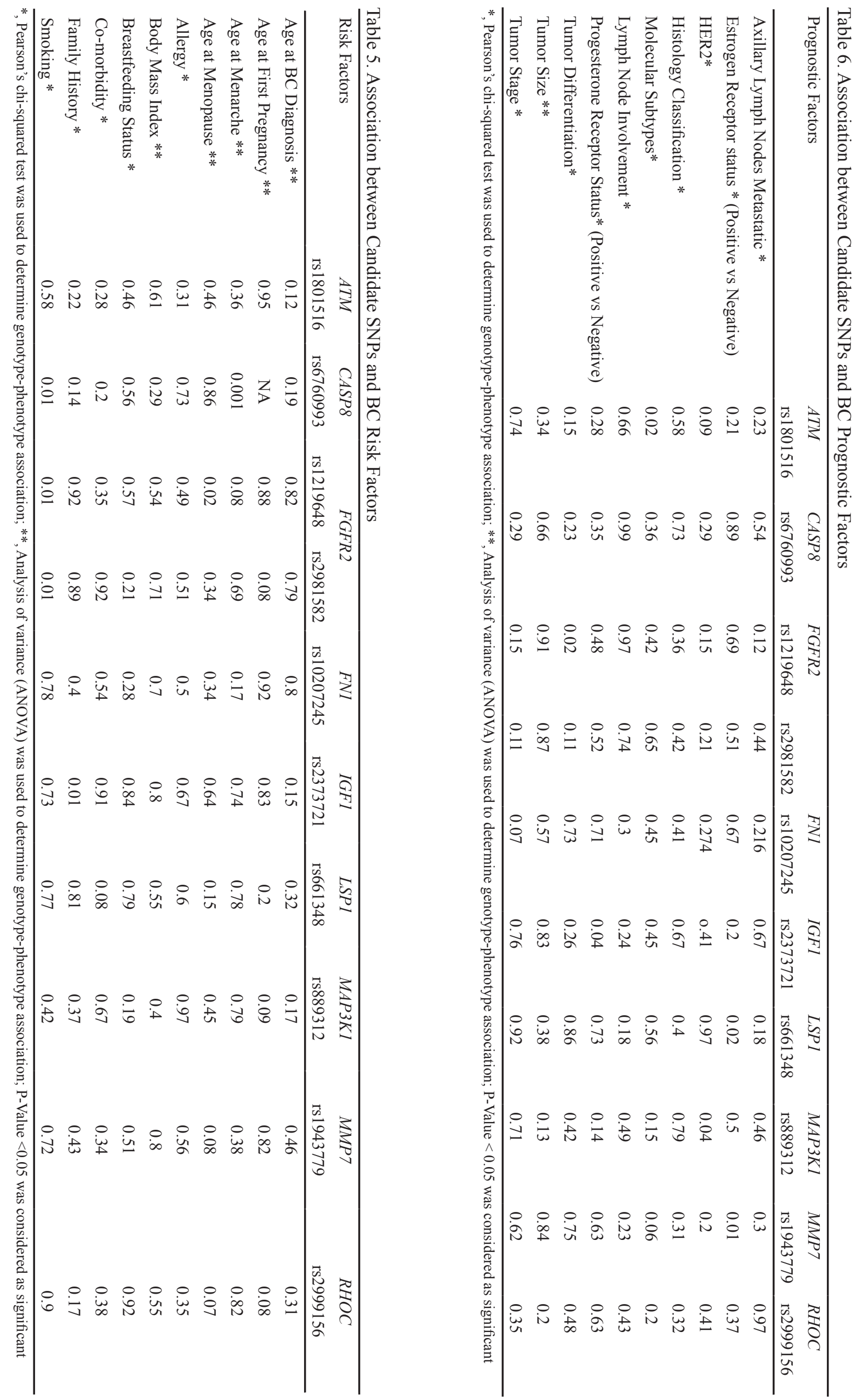
Table 7. Haplotypic Analysis of FGFR2 Polymorphisms

\begin{tabular}{lcccc}
\hline Haplotype & Frequency of Block & Frequency Ratio (Case : Control) (\%) & Odds Ratio (95\% CI) & P-value* \\
\hline & & FGFR2 & Block (rs1219648 and rs2981582) & \\
AG & 0.52 & $0.4857: 0.5571$ & 1 & NA \\
GA & 0.44 & $0.4741: 0.4103$ & $1.32(1.01-1.73)$ & 0.04 \\
AA & 0.02 & $0.0213: 0.0209$ & $1.19(0.48-2.95)$ & 0.71 \\
GG & 0.02 & $0.0188: 0.0117$ & $1.86(0.59-5.84)$ & 0.29 \\
\hline
\end{tabular}

Global haplotype association p-value: $0.19 ;{ }^{*} P$-Value $<0.05$ was considered as significant; NA, Not Applicable

non-smoking cases with the same genotype. In this regard, we hypothesize that AA genotype may increase the risk of developing BC among women. Correspondingly, the FGFR2 SNP rs 1219648 was associated with BC risk in the various populations, including African-Americans, Asians, and Caucasian-Americans (Rebbeck et al., 2008; Anderson et al., 2006; Zhang et al., 2017). Variation of the associations among different populations may be related to false-positive results due to population stratification. Environmental effects also contribute to genetic variation among the population. However, in this study, all subjects were genetically homogenous (native Arab ancestry). Haplotypic analysis indicated that the FGFR2 GA haplotype conferred a protective effect by reducing $\mathrm{BC}$ risk in Jordanian women. Different FGFR2 haplotypes such as GTGT in African-Americans and GTG in north Indians have been reported to increase BC risk (Siddiqui et al., 2014; Barnholtz-Sloan et al., 2010).

None of the other investigated SNPs showed any association with $\mathrm{BC}$ in Jordanian patients, but, upon the application of the dominant model (homozygote dominant GG vs heterozygote GA + recessive homozygote AA), the rs6760993 SNP of the CASP8 gene showed association with the disease $(\mathrm{p}$-value $=0.04)$. This finding reveal an involvement of the dominant genotype $\mathrm{GG}$ of CASP8 gene variant rs6760993 with $B C$ risk. rs6760993 was also linked to ages at menarche $(\mathrm{p}$-value $=0.001)$ and smoking $(\mathrm{p}$-value $=0.01)$. No previously published reports were found regarding the role of the CASP8 SNP rs6760993 in the context of BC suggesting that it is not pathogenic. A few SNPs other than rs6760993 in CASP8 are previously associated with subtype-specific breast cancer risk (Park et al., 2016). With regard to the remainder of SNPs, the FN1 SNP rs10207245 was associated with smoking ( $\mathrm{p}$-value $=0.01)$ while the IGF1 SNP rs2373721 was correlated with family history of $\mathrm{BC}(\mathrm{p}$-value $=0.01)$ and progesterone receptor status $(\mathrm{p}$-value $=0.04)$. Both SNPs were not reported in the context of $\mathrm{BC}$ in previous studies. In contrast, the MAP3K1 SNP rs889312, which was linked to HER2 marker status (p-value $=0.04$ ) in our study, was associated with increased BC risk in previously published literature (Rebbeck et al., 2008; Garcia-Closas and Chanock, 2008). Furthermore, our findings show that the LSP1 rs661348 and MMP7 rs1943779 SNPs were both significantly associated with estrogen receptor status. The C allele of the MMP7 rs1943779 SNP was previously shown to have a protective effect on distant metastasis development, but no such report was found for the LSP1 rs661348 SNP (Tapper et al., 2008).

It is apparent that $\mathrm{BC}$ etiology in Jordanian women is influenced by different genetic factors compared to those in other populations. While all of the genes included in this study had been previously shown to have a role in $\mathrm{BC}$ in other populations, only a select few exhibited a significant association with $\mathrm{BC}$ or its risk and prognosis in Jordanians. One limitation of this study is its relatively small sample size, although that can be offset by the fact that this is the first study to investigate these genes in the context of BC as it occurs in Jordan.

\section{Acknowledgements}

Authors are very greatly thankful to the Department of Biotechnology \& Genetic Engineering at Jordan University of Science and Technology, Irbid.

\section{Ethics approval and consent to participate}

All procedures performed in studies involving human participants were in accordance with the ethical standards of the Institutional Review Board (IRB) at Jordan University of Science and Technology with ethical code number (14/78/2014). Written informed consent was obtained from all individual participants included in the study.

\section{Funding}

This study was funded by the Deanship of Research (RN: 20140204), Jordan University of Science and Technology (JUST). There is no role for JUST in the design of the study; collection, analysis, and interpretation of data; and in writing the manuscript.

\section{Authors' contributions}

LNA-E designed and supervised the study. LNA-E, DMR and HA lead the implementation of the method, performed the data analysis. LNA-E, DMR and HA helped with the interpretation, description of the results and drafted the manuscript. Both authors read and approved the final manuscript.

\section{Conflicts of interest}

Authors declared that they have no conflict of interest in this work.

\section{References}

Abdel-Razeq H, Attiga F, Mansour A (2015). Cancer care in Jordan. Hematol Oncol Stem Cell Ther, 8, 64-70.

Ahmed M, Rahman N (2006). ATM and breast cancer susceptibility. Oncogene, 25, 5906-11. 
Al Qadire M, Alkhalaileh M, Hina H (2018). Risk factors for breast cancer among Jordanian women: A Case-control Study. Iran J Public Health, 47, 49-56.

AL-Eitan L, Rababa'h D (2020). Correlation between a variable number tandem repeat (VNTR) polymorphism in SMYD3 gene and breast cancer: a genotype-phenotype study. Gene, 728, 144281.

AL-Eitan L, Rababa'h D, Alghamdi M, Khasawneh R (2019A). Association of GSTM1, GSTT1 And GSTP1 Polymorphisms With Breast Cancer Among Jordanian Women. Onco Targets Ther, 12, 7757-65.

AL-Eitan L, Rababa'h D, Alghamdi M, Khasawneh R (2019B). Correlation between Candidate single nucleotide variants and several clinic pathological risk factors related to breast cancer in Jordanian women: A Genotype-Phenotype Study. J Cancer, 10, 4647-54.

AL-Eitan L, Rababa'h D, Alghamdi M, Khasawneh R (2019C). Role of four $\mathrm{ABC}$ transporter genes in pharmacogenetics susceptibility to breast cancer in Jordanian patients. J Oncol, 10, 1-8.

AL-Eitan L, Rababa'h D, Alghamdi M, Khasawneh R (2019D). Association of CYP gene polymorphisms with breast cancer risk and prognostic factors in the Jordanian population. $B M C$ Med Genet, 20, 148.

AL-Eitan LN, Rababa'h DM, Alghamdi MA, Khasawneh RH (2019E). Genetic association of XRCC5 gene polymorphisms with breast cancer among Jordanian women. OncoTargets Ther, 12, 7923-8.

AL-Eitan L, Rababa'h D, Alghamdi M, Khasawneh R (2019F). The influence of an IL-4 variable number tandem repeat (VNTR) polymorphism on breast cancer susceptibility. Pharm Genomics Pers Med, 12, 201-7.

AL-Eitan L, Rababa'h D, Alghamdi M, Khasawneh R (2019G). Association between ESR1, ESR2, HER2, UGT1A4, and UGT2B7 polymorphisms and breast cancer in Jordan: a case-control study. BMC Cancer, 19, 1-12.

AL-Eitan LN, Jamous RI, Khasawneh RH (2017). Candidate gene analysis of breast cancer in the Jordanian population of Arab descent: A Case-Control Study. Cancer Invest, 35, 256-70.

Anderson WF, Pfeiffer RM, Dores GM, Sherman ME (2006). Comparison of age distribution patterns for different histopathologic types of breast carcinoma. Cancer Epidemiol Biomarkers Prev, 15, 1899-1905.

Ando M, Kawazu M, Ueno T, et al (2013).Cancer associated missense mutations of caspase- 8 activate nuclear factorкBsignaling. Cancer Sci, 104, 1002-8.

Atoum MF, Al-Hourani HM (2004). Lifestyle related risk factors for breast cancer in Jordanian females. Saudi Med J, 25, 1245-8.

Atoum MF, Al-Kayed SA (2004). Mutation analysis of the breast cancer gene BRCA1 among breast cancer Jordanian females. Saudi Med J, 25, 60-3.

Awwad N, Yousef AM, Abuhaliema A, Abdalla I, Yousef M (2015). Relationship between genetic polymorphisms in MTHFR (C677T, A1298C and their Haplotypes) and the incidence of breast cancer among Jordanian females: CaseControl Study. Asian Pac J Cancer Prev, 16, 5007-11.

Barnholtz-Sloan JS, Shetty PB, Guan X, et al (2010). FGFR2 and other loci identified in genome-wide association studies are associated with breast cancer in African-American and younger women. Carcinogenesis, 31, 1417-23.

Bar-Shavit R, Maoz M, Kancharla A, et al (2016). G proteincoupled receptors in cancer. Int J Mol Sci, 17, 1320.

Basu S, Thorat R, Dalal SN (2015). MMP7 is required to mediate cell invasion and tumor formation upon Plakophilin3 loss. PLoS One, 10, e0123979.
Beeghly-Fadiel A, Shu X-O, Long J, et al (2009). Genetic polymorphisms in the MMP-7 gene and breast cancer survival. Int $J$ Cancer, 124, 208-14.

Brahmkhatri VP, Prasanna C, Atreya HS (2015). Insulin-like growth factor system in cancer: novel targeted therapies. Biomed Res Int, 2015, 1-24.

Capra M, Nuciforo PG, Confalonieri S, et al (2006). Frequent Alterations in the expression of Serine/Threonine Kinases in human cancers. Cancer Res, 66, 8147-54.

Chen H, Qi X, Qiu P, Zhao J (2015). Correlation between LSP1 polymorphisms and the susceptibility to breast cancer. Int $J$ Clin Exp Pathol, 8, 5798-802.

Christopoulos PF, Msaouel P, Koutsilieris M (2015). The role of the insulin-like growth factor-1 system in breast cancer. Mol Cancer, 14, 43.

Easton DF, Pooley KA, Dunning AM, et al (2007). Genome-wide association study identifies novel breast cancer susceptibility loci. Nature, 447, 1087-93.

Gage M, Wattendorf D, Henry LR (2012). Translational advances regarding hereditary breast cancer syndromes. J Surg Oncol, $105,444-51$.

Garcia-Closas M, Chanock S (2008). Genetic susceptibility loci for breast cancer by estrogen receptor status. Clin Cancer Res, 14, 8000-9.

Gialeli C, Theocharis AD, Karamanos NK (2011). Roles of matrix metalloproteinases in cancer progression and their pharmacological targeting. FEBS J, 278, 16-27.

Graf RP, Keller N, Barbero S, Stupack D (2014). Caspase-8 as a regulator of tumor cell motility. Curr Mol Med, 14, 246-54.

Hankinson SE, Colditz GA, Willett WC (2004). Towards an integrated model for breast cancer etiology: The lifelong interplay of genes, lifestyle, and hormones. Breast Cancer Res, 6, 213.

Helleman J, Jansen MP, Ruigrok-Ritstier K, et al (2008). Association of an extracellular matrix gene cluster with breast cancer prognosis and endocrine therapy response. Clin Cancer Res, 14, 5555-64.

Helsten T, Elkin S, Arthur E, et al (2016). The FGFR landscape in cancer: Analysis of 4,853 tumors by next-generation sequencing. Clin Cancer Res, 22, 259-67.

Horiuchi A, Imai T, Wang C, et al (2003). Up-regulation of small GTPases, RhoA and RhoC, is associated with tumor progression in ovarian carcinoma. Lab Invest, 83, 861-70.

Jang JH, Shin KH, Park YJ, et al (2000). Novel transcripts of fibroblast growth factor receptor 3 reveal aberrant splicing and activation of cryptic splice sequences in colorectal cancer. Cancer Res, 60, 4049-52.

Jerzak KJ, Mancuso T, Eisen A (2018). Ataxia-telangiectasia gene (ATM) mutation heterozygosity in breast cancer: a narrative review. Curr Oncol, 25, 176-80.

Katoh M (2016). FGFR inhibitors: Effects on cancer cells, tumor microenvironment and whole-body homeostasis (Review). Int J Mol Med, 38, 3-15.

Lang S, Busch H, Boerries M, et al (2017). Specific role of RhoC in tumor invasion and metastasis. Oncotarget, 8, 87364-78.

Lavin MF, Delia D, Chessa L (2006). ATM and the DNA damage response. Workshop on ataxia-telangiectasia and related syndromes. EMBO Rep , 7, 154-60.

Lee EYHP, Muller WJ (2010). Oncogenes and tumor suppressor genes. Cold Spring Harb Perspect Biol, 2, a003236.

Li C, Egloff AM, Sen M, Grandis JR, Johnson DE (2014). Caspase- 8 mutations in head and neck cancer confer resistance to death receptor-mediated apoptosis and enhance migration, invasion, and tumor growth. Mol Oncol, 8, $1220-30$.

Li J, Ji L (2005). Adjusting multiple testing in multilocus analyses using the eigenvalues of a correlation matrix. 
Heredity, 95, 221-7.

Nyholt DR (2004). A simple correction for multiple testing for single-nucleotide polymorphisms in linkage disequilibrium with each other. Am J Hum Genet, 74, 765-9.

Park HL, Ziogas A, Chang J, et al (2016). Novel polymorphisms in caspase- 8 are associated with breast cancer risk in the California Teachers Study. BMC Cancer, 16, 14.

Pham TT, Angus SP, Johnson GL (2013). MAP3K1: Genomic alterations in cancer and function in promoting cell survival or apoptosis. Genes Cancer, 4, 419-26.

$\mathrm{Pu}$ X, Storr SJ, Zhang Y, et al (2017). Caspase-3 and caspase-8 expression in breast cancer: caspase- 3 is associated with survival. Apoptosis, 22, 357-68.

Rebbeck TR, DeMichele A, Tran TV, et al (2009). Hormonedependent effects of FGFR2 and MAP3K1 in breast cancer susceptibility in a population-based sample of postmenopausal African-American and European American women. Carcinogenesis, 30, 269-74.

Renwick A, Thompson D, Seal S, et al (2006). ATM mutations that cause ataxia-telangiectasia are breast cancer susceptibility alleles. Nat Genet, 38, 873-5.

Rodriguez S, Gaunt TR, Day IN (2009). Hardy-Weinberg equilibrium testing of biological ascertainment for Mendelian randomization studies. Am J Epidemiol, 169, 505-14.

Sadek RF, Zhang LF, Abdul Sater HT (2017). Breast cancer molecular subtypes association with clinical outcomes and race. J Clin Oncol, 35, 12575.

Siddiqui S, Chattopadhyay S, Akhtar MS, et al (2014). A study on genetic variants of fibroblast growth factor receptor 2 (FGFR2) and the risk of breast cancer from north India. PLoS One, 9, e110426.

Sole X, GuinoE, Valls J, Iniesta R, Moreno V (2006). SNPStats: a web tool for the analysis of association studies. Bioinformatics, 22, 1928-9.

Tapper W, Hammond V, Gerty S, et al (2008). The influence of genetic variation in 30 selected genes on the clinical characteristics of early onset breast cancer. Breast Cancer Res, 10, R108.

Vachon CM, Scott CG, Fasching PA, et al (2012). Common breast cancer susceptibility variants in LSP1 and RAD51L1 are associated with mammographic density measures that predict breast cancer risk. Cancer Epidemiol Biomarkers Prev, 21, 1156-66.

Wang JP, Hielscher A (2017). Fibronectin: How its aberrant expression in tumors may improve therapeutic targeting. J Cancer, 8, 674-82.

Wang Y, Xu H, Zhu B, Qiu Z, Lin Z (2018). Systematic identification of the key candidate genes in breast cancer stroma. Cell Mol Biol Lett, 23, 44.

Yang SY, Miah A, Pabari A, Winslet M (2011). Growth Factors and their receptors in cancer metastases. Front Biosci (Landmark Ed), 16, 531-8.

Zhang B, Beeghly-Fadiel A, Long J, Zheng W (2011). Genetic variants associated with breast-cancer risk: comprehensive research synopsis, meta-analysis, and epidemiological evidence. Lancet Oncol, 12, 477-88.

Zhang H, Wang Y, Liu Z, et al (2016). Lymphocyte-specific protein 1 inhibits the growth of hepatocellular carcinoma by suppressing ERK1/2 phosphorylation. FEBS Open Bio, 6, 1227-37.

Zhang Y, Lu H, Ji H, et al (2017). Association between rs11200014, rs2981579, and rs1219648 polymorphism and breast cancer susceptibility. Medicine (Baltimore), 96, e9246.
This work is licensed under a Creative Commons AttributionNon Commercial 4.0 International License. 